P.В. Мордас, магистрант

Л.Н.Лебедь, к.т.н., доцент

Национальный технический университет Украины «Киевский политехнический институт имени Игоря Сикорского» МОДЕЛИРОВАНИЕ ТЕПЛОВОГО СОСТОЯНИЯ ЗДАНИЯ С СИСТЕМОЙ ТЕРМОАКТИВНОГО УТЕПЛЕНИЯ

В статье описано новую систему теплоснабжения, которая может использоваться как для новых домов, так и для реконструкции старых зданий, где система отопления уже исчерпала свой ресурс и не подлежит восстановлению. Рассмотрено систему термоактивного утепления отопления и охлаждения, основными преимуществами которой является работа с низкотемпературными источниками теплотьл (тепловые насосы, солнечные коллекторы и др.) Предложено теплогидравлическую схему работы данной системы в сочетании с инновачионным оборудования. Проведено CFD моделирование температурного режима части корпуса теплоэнергетического факультета КПИ им. Игоря Сикорского.. Получень температурные поля и распределения скорости воздуха в помещении, расходы тепловой энергии для отопления помещений в двух случаях: до термодернизации и после ее выполнения. В связи с возросшей эффективностью работы тепловых насосов в низкотемпературном режиме имеем разнииу в расходе энергии на поддержание температурного состояния здания в 8 раз. Характерной особенностью данной системы также является возможность работы в режиме кондиционирования помещений.

Ключевые слова: термоактивные конструкции, термоактивное утепление, система теплоснабжения, температурное состояние зданий, тепловой насос.

Надійшла 15.03.2018

Надійшла 15.03.2018

УДК 622.276

Л.К. Лістовщик, канд. техн. наук, доц., ORCID 0000-0003-3413-1802

О.В. Лотонова, студентка.

Національний технічний університет України «Київський політехнічний інститут імені Ігоря

Сікорського»

\title{
ЕНЕРГООЩАДНА СИСТЕМА ЗАПОБІГАННЯ ПРОЦЕСУ ВІДКЛАДЕННЯ ПАРАФІНІВ НА СТІНКАХ НАФТОВОЇ СВЕРДЛОВИНИ
}

\footnotetext{
Представлено результати аналітичних досліджень системи обігріву труби НКТ з метою запобігання відкладення парафінів на ї̈ стінках з використанням як електрокабелю, так $і$ нагрітого контуру теплового насосу. Проведено аналіз результатів та вибрано спосіб нагріву труб $з$ використанням теплового насосу.

Доведено, щу при використанні теплового насосу для нагрівання труби, порівняно з використанням електрокабелю, відбувається значне скорочення енерговитрат $і$ грошових витрат на придбання електроенергії.
}

Ключові слова: нафтова свердловина, тепловий насос, парафінова пробка, кабель для нагріву 


\section{ISSN 1813-5420 (Print). Енергетика: економіка, технології, екологія. 2018. № 1}

Вступ. Розвиток нафтогазової промисловості в Україні потребує підвищення ефективності методів розробки родовищ і збільшення нафтовіддачі пластів. Важлива роль у вирішенні цієї задачі відводиться новітнім дослідженням в області нафтовидобутку і використання науково-дослідних розробок в процесах підвищення нафтовіддачі.

В процесі руху нафти від пласта до поверхні, наприклад, при фонтанній експлуатації, або експлуатації свердловини насосними установками, температура порід навколо свердловини зменшується, а отже, температура нафти теж зменшується і стає нижчоюу за температуру плавлення парафіну, який $\epsilon$ присутнім в нафті. Парафін починає осідати на холодних стінках свердловини, утворюючи так звану парафінову пробку, яка спочатку зменшує прохідний отвір для руху рідини, а згодом зовсім перекриває іiі рух і стопорить штанги при експлуатації свердловини штанговою свердловинною насосною установкою (ШСНУ) [1].

У наведеній статті висвітлено два способи запобігання процесу відкладення парафінів на стінках нафтової свердловини $з$ використанням електрокабелю та теплового насосу, наведені результати аналітичних досліджень основних параметрів.

Метою роботи $є$ аналітичне обгрунтування основних параметрів енергоощадної системи запобігання процесу відкладення парафінів на стінках нафтової свердловини.

Постановка задачі Для досягнення мети необхідно аналітично визначити основні параметри процесу нагріву труби НКТ за допомогою електрокабелю та теплового насосу, порівняти способи, обгрунтувати вибір раціонального енергоощадного способу нагріву.

\section{Матеріали і результати досліджень}

Існує багато способів запобігання відкладенню парафінів на елементах конструкції свердловини. Це механічний спосіб, використання водяного пару, хімічні методи та ін. [2].

Найбільш близьким технічним рішенням до запропонованого в статті $є$ використання для підігріву труб електрокабеля, який нагрівається за допомогою струму, який протікає в ньому [3], тому є доцільним порівняти запропоновану систему саме з цим методом.

Запропонована система запобігання процесу відкладення парафіну на стінках нафтової свердловини вирішуе поставлену задачу використанням теплового насосу в якому вхідний контур з'єднаний 3 вихідними трубами теплообмінника, який відбирає тепло від рідини, що циркулює в допоміжній свердловині, а вихідний контур теплового насосу у вигляді гнучкої труби навитий на насосно-компресорну трубу (НКТ) свердловини, яка експлуатується, при цьому циркуляція рідини у трубі відбувається за допомогою циркуляційного насосу [4].

Це технічне рішення дозволяє запобігти процесу відкладення парафіну на стінках свердловини завдяки підігріву стінок свердловини відібраним теплом від іншої свердловини за допомогою теплового насоса до температури, яка перевищує температуру плавлення парафіну.

Система запобігання процесу відкладення парафіну на стінках нафтової свердловини (рис. 1) містить тепловий насос 1 з вихідним трубопроводом 2 , який розташований в стовбурі діючої свердловини 3 та вхідним трубопроводом 4 , який 3 насосом 5 з'єднаний з вихідними трубами теплообмінника 6 , що відбирає тепло від рідини, яка циркулює в допоміжній свердловині 7 за допомогою насоса 8. Вихідний контур 2 теплового насосу у вигляді гнучкої труби навитий на трубу НКТ свердловини, яка експлуатується, при цьому циркуляція рідини у трубі відбувається за допомогою насоса 9.

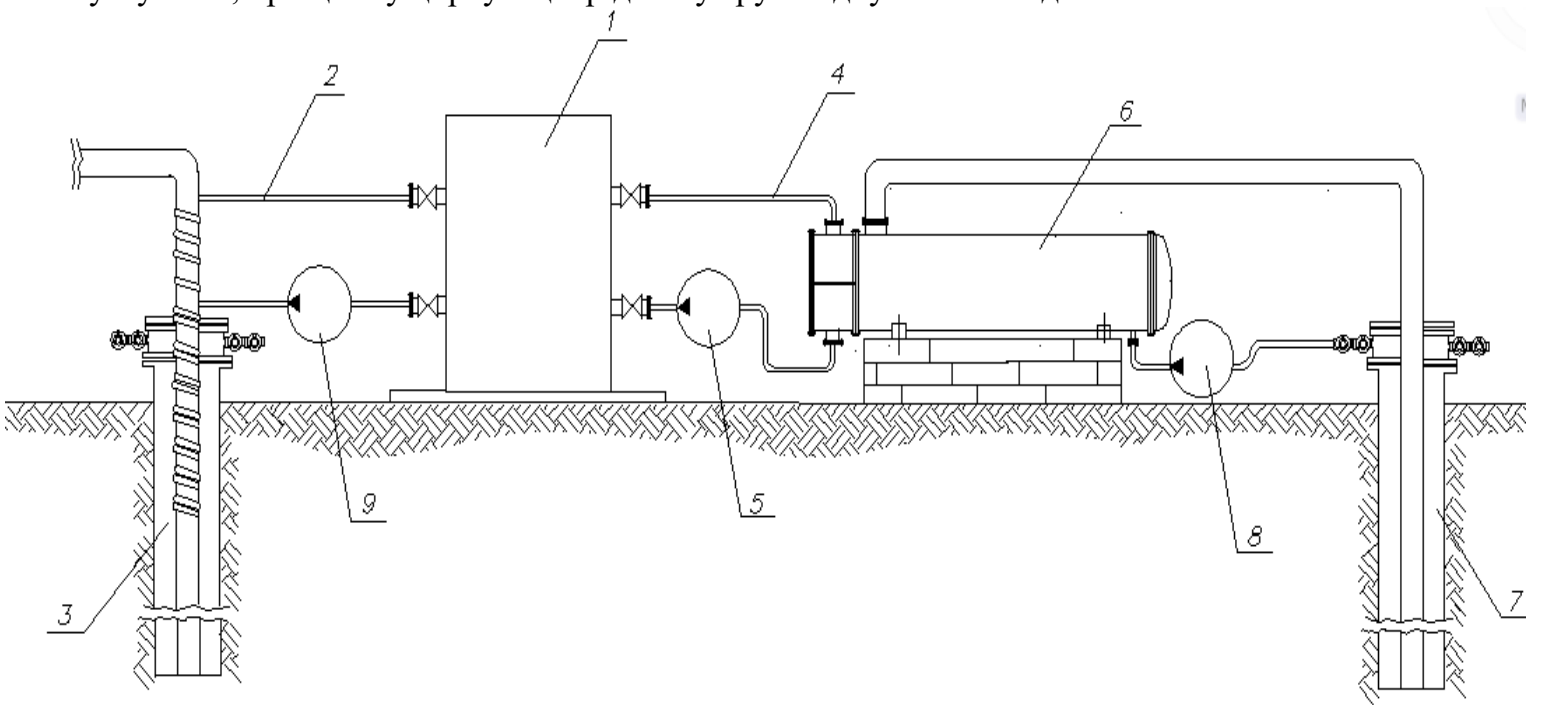

Рисунок 1 - Система запобігання процесу відкладення парафінів на стінках нафтової свердловини 
Принцип роботи системи. Рідина, яка циркулює в допоміжній свердловині, за допомогою насоса 8 перекачується по трубопроводу до вхідного контуру теплообмінника 6. Теплообмінник відбирає тепло. За допомогою насоса 5 рідина перекачується на вхід теплового насоса 1 по трубопроводу 4 . У вихідному контурі теплового насосу теплоносій нагрітий до $75^{\circ} \mathrm{C}$, а контур навитий на трубу НКТ свердловини, яка експлуатується 3, по якій високопарафініста нафта надходить на поверхню. Рідина, яка потрапляє у вихідний трубопровід 2 теплового насосу обігріває трубу НКТ свердловини, тим самим запобігаючи процесу відкладення парафіну на іï стінках. Циркуляція рідини у витках відбувається за допомогою насоса 9.

Підігріта нафта надходить із свердловини в ємності, які знаходяться на поверхні, де і осідає парафін. Очистка таких ємностей від парафінів не становить великої проблеми.

За методикою, яка описана в [5] розраховано та вибрано 3 ряду типових теплообмінників оптимальний з точки зору ефективності теплопередачі, в якому 100000 кг/год. нафти змінює свою температуру $з t_{1 н}$ до $70^{\circ} \mathrm{C}$ за рахунок теплообміну з 90000 кг/год. води, що має початкову температуру $20^{\circ} \mathrm{C}$ і кінцеву температуру $60{ }^{\circ} \mathrm{C}$. Теплоємність нафти $\mathrm{c}_{1}=2,72 \mathrm{\kappa Д} / \mathrm{\kappa} \Gamma \cdot \mathrm{K}$, теплоємність води $\mathrm{c}_{2}=4,218$ кДж/кг $\cdot$ К.

Це кожухотрубний теплообмінник, який має такі параметри та їх значення:

- площа поверхні теплообміну $-F=509 \mathrm{~m}^{2}$;

- довжина труб $-L=9$ м;

- діаметр кожуха $-D_{\kappa}=1,2 \mathrm{M}$;

- зовнішній діаметр труб $-d_{r}=0,02 \mathrm{~m}$;

- внутрішній діаметр труб $-d_{6 H}=0,016$ м;

- кількість труб $-n=986$.

В якості альтернативи розглянуто метод обігріву труби НКТ електричним кабелем КнМНбФэ-1,51000-200 [3] і були використані такі ж вхідні умови, як і для обігріву за допомогою теплового насосу.

Аналіз розрахунків показав, що для обігріву труби НКТ з нафтою за допомогою гнучкої вихідної труби теплового насосу втрати по всій довжині ділянки, що обігрівається, труби НКТ склали 21510 Вт, а електропроводом 52787 Вт, потужність яка необхідна для обігріву 1 погонного метра труби НКТ у першому способі склала 53 Вт/м, а у другому - $131 \mathrm{BT} / \mathrm{м}$.

Взявши за основу вартість електроенергії на грудень 2017 року, проведено порівняння обох способів нагріву. Витрати на підігрів труби НКТ від електрокабеля склали 22736 грн. за рік, а від теплового насосу 7968 грн. за рік. Отже, при експлуатації свердловини після заміни способу нагрівання з електрокабеля на тепловий насос, річний економічний ефект складе $\mathrm{Ep}=14768$ грн.

Термін окупності системи запобігання процесу відкладення парафінів складає 4,8 років.

\section{Висновок}

Отже, з точки зору енерговитрат та капітальних витрат на функціонування системи запобігання відкладенню парафінів в свердловині, доцільним $€$ використання саме теплового насосу. Термін окупності в 4,8 роки обумовлений більшою вартістю елементів теплового насосу та роботами по встановленню його елементів на свердловині.

\section{Список використаної літератури}

1. Персіянцев М.Н. Видобуток нафти в ускладнених умовах. - М .: ТОВ "Надра-Бізнесцентр", 2000. $-653 \mathrm{c}$.

2. Метод газоимпульсной обработки скважин / Зотов В.С., Альнабуда А.С.Д, Губарь В.А., Караогланов С.А. - СПб.: «Галея Принт», 2004. - 200 с.

3. Продукция для нефтегазового комплекса [Електронний ресурс] / ООО Псковкабель. С.22. Режим доступу http://pskovgeokabel.ru/products/1_24/

4. Пат. 119701 Україна, МПК (2006.01) E21B 43/34, F24J 3/08 Пристрій запобігання процесу відкладення парафіну на стінках нафтової свердловини / Лотонова О.В., Лістовщик Л.К., Шевчук С.П., Задвернюк В.В.; заявник і власник патенту Національний технічний університет України «Київський політехнічний інститут імені Ігоря Сікорського». - №u2017 01412 заявл. 15.02.2017; опубл. 10.10.2017, Бюл. №19.

5. Т.О. Ринкова, В.П. Баб’як, В.І. Шкляр. Кожухотрубний теплообмінник: Методичні вказівки до виконання розрахункової частини курсового проекту з дисципліни "Теплотехнічні процеси та установки" для студентів усіх форм навчання спеціальності "Енергетичний менеджмент" - К.: ІВЦ Видавництво «Політехніка», 2005. - $50 \mathrm{c}$. 
L. Listovshchyk, Cand. Sc. (Eng), Assoc. Prof., ORCID 0000-0003-3413-1802

O. Lotonova, student

National Technical University of Ukraine "Igor Sikorsky Kyiv Polytechnic Institute"

\section{ENERGY-SAVING SYSTEM TO PREVENT OF THE PROCESS OF PARAFFIN ACCUMULATION ON THE WALLS OF AN OIL WELL}

The results of analytical researches of the tubing heating system of tubes are presented in order to prevent the deposition of paraffins on its walls using the electric cable and the heated circuit of the heat pump. The analysis of the results was carried out and the method of heating the pipes with the use of a heat pump was chosen.

Was proved that when using a heat pump for heating a pipe, in comparison with the use of an electric cable, energy costs and money costs for the purchase of electric power are significantly reduced.

Keywords: oil well, heat pump, paraffin cap, heating cable.

References $-653 \mathrm{~s}$.

1. Persiyantsev M.N. Vydobutok nafty v uskladnenykh umovakh. - M .: TOV "Nadra-Biznestsentr", 2000.

2. Metod hazoympul'snoy obrabotky skvazhyn / Zotov V.S., Al'nabuda A.S.D, Hubar' V.A., Karaohlanov S.A. - SPb.: «Haleya Prynt», 2004. - 200 s.

3. Produktsyya dlya neftehazovoho kompleksa [Elektronnyy resurs] / OOO Pskovkabel'. S.22. Rezhym dostupu http://pskovgeokabel.ru/products/1_24/

4. Pat. 119701 Ukrayina, MPK (2006.01) E21V 43/34, F24J 3/08 Prystriy zapobihannya protsesu vidkladennya parafinu na stinkakh naftovoyi sverdlovyny / Lotonova O.V., Listovshchyk L.K., Shevchuk S.P., Zadvernyuk V.V.; zayavnyk i vlasnyk patentu Natsional'nyy tekhnichnyy universytet Ukrayiny «Kyyivs'kyy politekhnichnyy instytut imeni Ihorya Sikors'koho». - \#u2017 01412 zayavl. 15.02.2017; opubl. 10.10.2017, Byul. \#19.

5. T.O. Rynkova, V.P. Bab"yak, V.I. Shklyar. Kozhukhotrubnyy teploobminnyk: Metodychni vkazivky do vykonannya rozrakhunkovoyi chastyny kursovoho proektu z dystsypliny "Teplotekhnichni protsesy ta ustanovky" dlya studentiv usikh form navchannya spetsial'nosti "Enerhetychnyy menedzhment" - K.: IVTs Vydavnytstvo «Politekhnika», 2005. - $50 \mathrm{~s}$.

Л.К. Листовщик, канд. техн. наук, доц. ORCID 0000-0003-3413-1802,

О.В. Лотонова, студентка.

Национальный технический университет Украины «Киевский политехнический институт имени Игоря Сикорского»

\section{ЭНЕРГОСБЕРЕГАЮЩАЯ СИСТЕМА ПРЕДОТВРАЩЕНИЯ ПРОЦЕССА ОТЛОЖЕНИЯ ПАРАФИНА НА СТЕНКАХ НЕФТЯНЫХ СКВАЖИН}

Представлены результаты аналитических исследований системы обогрева трубы НКТ с иелью предотвращения отложения парафинов на ее стенках с использованием как греющего электрокабеля, так и контура теплового насоса. Проведен анализ результатов и выбран способ нагрева труб с использованием теплового насоса.

Доказано, что при использовании теплового насоса для нагрева трубы, по сравнению с использованием электрокабеля, происходит значительное сокращение энергозатрат и денежных затрат на электроэнергию.

Ключевые слова: нефтяная скважина, тепловой насос, парафиновая пробка, кабель для нагрева. 